\title{
IMPROVING INSTRUCTIONAL PROCESS IN UTILIZING THE SCHOOL ENVIRONMENT THROUGH THE TEACHERS' WORK GROUP DISCUSSION AT ELEMENTARY SCHOOLS
}

\author{
Endawinarti ${ }^{1}$, Fefi Yulita ${ }^{2}$ \\ ${ }^{1}$ SDN 16 Simpang Haru, Padang, Indonesia \\ ${ }^{2}$ SDN 29 Ganting Utara, Padang, Indonesia \\ 1endawinarti80@gmail.com, ${ }^{2} y$ ulifefi9@gmail.com
}

\begin{abstract}
This research was motivated by the problems found that teachers did not optimally implement the learning process at elementary schools. It was found that many teachers still did not carry out the learning process in accordance with the characteristics of elementary school students, so efforts were needed to improve it. The purpose of this research was to improve the learning process of elementary school teachers which included lesson planning, implementation of learning, and assessment of learning outcomes through KKG discussion activities. The learning process that would be improved was the process using an investigative group type cooperative model. This research was a school action research by adapting the process of implementing Mc Taggart and Kemmist's classroom action research. This research consisted of stages of planning, implementation, observation and reflection. Based on the research conducted, it was found that the teachers' average skill score in cycle 1 was 66.32 and an average score in cycle 2 was 85.66. This concluded that there was an increase in the teacher learning process skills through KKG activities. The implications of this research was that it could be used as an effort for supervisors to improve teacher skills.
\end{abstract}

Keywords: learning, teacher working group, supervision

\section{PENINGKATAN PROSES PELAKSANAAN PEMBELAJARAN GURU DALAM PEMANFAATAN LINGKUNGAN SEKOLAH SEKOLAH MELALUI DISKUSI KELOMPOK KERJA GURU SEKOLAH DASAR}

\begin{abstract}
ABSTRAK
Penelitian ini dilatarbelakangi oleh adanya permasalahan yang ditemukan bahwa guru belum optimal melaksanakan proses pembelajaran disekolah dasar. Guru ditemukan masih banyak tidak melaksanakan proses pembelajaran yang sesuai dengan karakteristik siswa sekolah dasar, sehingga diperlukan upaya untuk memperbaikinya. Tujuan penelitian ini adalah untuk meningkatkan proses pembelajaran guru sekolah dasar yang meliputi perencanaan pembelajaran, pelaksanaan pembelajaran dan penilaian hasil belajar melalui kegiatan diskusi KKG. Proses pembelajaran yang akan ditingkatkan yaitu proses pembelajaran menggunakan model kooperatif tipe group investigasi. Penelitian ini merupakan penelitian tindakan sekolah dengan menyadur proses pelaksanaan penelitian tindakan kelas Mc Taggart dan Kemmist. Penelitian ini terdiri dari tahap perencanaan, pelaksanaan, pengamatan dan refleksi. Berdasarkan penelitian yang dilakukan ditemukan guru mendapatkan skor rata-rata keterampilan pada siklus 1 sebesar 66.32 dan mendapatkan skor rata-rata pada siklus 2 sebesar 85.66. Hal ini menyimpulkan bahwa terjadinya peningkatan keterampilan proses pembelajaran guru melalui kegiatan KKG. Implikasi penelitian ini dapat dijadikan sebagai upaya bagi supervisor untuk dapat meningkatkan keterampilan guru.
\end{abstract}

Kata Kunci: pembelajaran, kelompok kerja guru, supervisi.

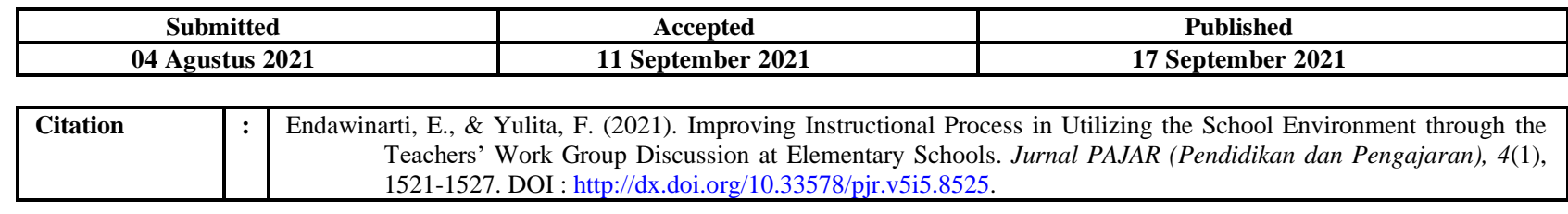

\section{PENDAHULUAN}

Pemerintah selalu berupaya dalam meningkatkan kualitas pendidikan dengan melakukan penyempurnaan kurikulum (Eliyasni et al, 2019). Proses pelaksanaan kurikulum yang awalnya bersifat sentralistik mengakibatkan proses kemampuan perkembangan kognitif siswa menjadi tidak fleksibel sehingga siswa sulit untuk menerima pendapat yang bersifat divergen (Hendri and Kenedi, 2018). Siswa merasa puas dengan apa yang sudah didapatkan tanpa adanya upaya untuk menggali lebih dalam mengenai 
materi yang sudah didapatkan. Hal ini mengakibatkan kurang berkembangnya proses pemikiran siswa dan siswa cendrung malas untuk aktif dalam menemukan informasi baru. Proses pembelajaran yang pada awalnya hanya lebih menfokuskan kepada kemampuan menghafal dan mengingat sehingga proses pembelajaran yang dilaksanakan menjadi tidak bermakna. Maka upaya pemerintah untuk merubah system pendidikan seperti ini dengan merubah kurikulum.

Kurikulum 2013 merupakan kurikulum penyempurnaan dari pada kurikulum sebelumnya. Kurikulum 2013 merupakan kurikulum yang menggunakan pendekatan tematik terpadu (Hamimah et al, 2019). Kurikulum 2013 merubah system pembelajaran yang awalnya bersifat teacher center menjadi proses pembelajaran yang bersifat student center (Hendri et al, 2019). Dalam proses pembelajaran pada kurikulum 2013, guru selain menggunakan model pembelajaran yang telah ditetapkan juga diperbolehkan untuk memilih model pembelajaran yang sesuai dengan karakteristik proses pembelajaran disekolah dasar (Hendri et al, 2019). Guru sekolah dasar harus mampu memilih model pembelajaran yang dapat mengembangkan kemampuan berpikir siswa (Hamimah et al, 2019; Sukirno et al, 2020).

Salah satu model pembelajaran yang dapat digunakan pada proses pembelajaran disekolah dasar adalah model pembelajaran kooperatif (Hakkarainen, 2013; Slavin, 2015; Yeah et al 2018). Model pembelajaran kooperatif merupakan sebuah model pembelajaran yang dapat membuat siswa aktif berkerjasama dalam menemukan informasi (Gillies, 2016; Hidayat and Muhson, 2018; Dzemidzic Kristiansen, 2019). Model pembelajaran kooperatif merupakan sebuah model pembelajaran yang menuntut siswa untuk dapat salin berinteraksi dan berkolaborasi dalam proses pembelajaran (Zaman, 2020). Banyak penelitian yang menyatakan bahwa model pembelajaran kooperatif tepat digunakan pada proses pembelajaran disekolah dasar (Kristiawan, 2013; Genç, 2016; Maman and Rajab, 2016).

Salah satu model pembelajaran kolaboratif yang tepat digunakan pada proses pembelajaran disekolah dasar adalah model kooperatif tipe group investigation. Model kooperatif tipe group investigation merupakan sebuah model pembelajaran yang memfasilitasi siswa untuk dapat belajar dalam kelompok kecil yang bersifat heterogen untuk dapat menyelesaikan permasalahan secara Bersama (Gading et al, 2017). Hal inilah yang menjadikan model kooperatif tipe group investigation cocok dan sesuaik dengan karakteristik pembelajaran disekolah dasar. Pembelajaran disekolah dasar merupakan pembelajaran yang dilaksanakan dengan menggunakan benda kongkret maupun melibatkan siswa secara aktif melalui pengalaman langsung siswa (Kiswanto, 2017; Kenedi et al, 2019). Berdasarkan kajian literatur yang peneliti lakukan ditemukan bahwa pembelajaran dengan menggunakan model kooperatif tipe group investigation dapat meningkatkan kualitas pembelajaran siswa sekolah dasar (Hastuti, 2020; Novita et al, 2021). Oleh sebab itu model kooperatif tipe group investigation sangat tepat digunakan untuk pembelajaran disekolah dasar. Teruatama disekolah yang peneliti pimpin.

Peneliti merupakan seorang kepala sekolah. Berdasarkan temuan peneliti terhadap proses pembelajaran di SDN 16 Simpang Haru Kota Padang ditemukan proses pembelajaran yang dilaksanakan oleh guru masih didominasi dengan metode ceramah. Untuk itu peneliti melakukan proses dokumentasi terhadap RPP yang digunakan oleh guru. Berdasarkan temuan terlihat bahwa guru menggunakan RPP yang di download dari internet tanpa dikembangan sendiri. Temuan lainnya juga terlihat bahwa guru hanya berfokus terhadap penilaian pengetahuan siswa saja. Berdasarkan analisis peneliti disimpulkan bahwa proses pembelajaran yang dilaksanakan oleh guru masih belum sesuai dengan karakteristik proses pembelajajaran kurikulum 2013 untuk siswa sekolah dasar yang meliputi perencanaan pembelajaran, pelaksanaan pembelajaran dan penilaian hasil belajar.

Permasalahan harus segara diatasi. Hal ini dikarenakan proses pembelajaran yang dilaksanakan oleh guru akan berpengaruh terhadap proses pencapaian tujuan pembelajaran siswa yang berdampak kepada kualitas dan mutu 
pembeajaran. Salah satu upaya yang dapat dilakukan adalah dengan melakukan diskusi kelompok kerja guru (KKG). KKG merupakan sebuah aktivitas yang berisikan guru sekolah dasar dengan tujuan untuk meningkatkan kompetensi guru dalam melaksanakan proses pembelajaran disekolah (Yus, 2020). Proses KKG ini dapat berupa workshop, diskusi, dan simulasi. Berdasarkan kajian literatur yang peneliti lakukan ditemukan bahwa KKG dapat meningkatkan kualitas pembelajaran guru (Lubis, 2017; Sukirman, 2020). Oleh sebab itu peneliti ingin mengatasi permasalahan tersebut melalui kegiatan KKG.

Penelitian ini didukung oleh penelitian sebelumnya yang dilakukan oleh Alwi (2009) yang menyatakan bahwa kegiatan KKG dapat meningkatan kemampuan guru dalam melaksanakan proses pembelajaran. Namun menjadi penelitian yang berbeda karena penelitia ini difokuskan kepada proses pembelajaran yang meliputi perencanaan pembelajaran, pelaksanaan pembelajaran dan penilaian hasil belajar dengan menggunakan model kooperatif tipe group investigation. Oleh sebab itu tujuan penelitian ini adalah untuk meningkatkan proses pembelajaran guru sekolah dasar yang meliputi perencanaan pembelajaran, pelaksanaan pembelajaran dan penilaian hasil belajar melalui kegiatan diskusi KKG.

\section{METODE PENELITIAN}

Penelitian ini merupakan penelitian tindakan sekolah dengan menyadur proses pelaksanaan penelitian tindakan kelas $\mathrm{Mc}$ Taggart dan Kemmist. Penelitian ini terdiri dari tahap perencanaan, pelaksanaan, pengamatan dan refleksi. Pada tahapan perencanaan peneliti menyusun jadwal, penyusun rencana kegiatan dan penyusun instrument penilaian. Pada tahapan pelaksanaan peneliti melakukan kegiatan KKG. Pada tahapan pengamatan dilakukan proses penilaian kepada guru dan pada tahapan refleksi dilakukan proses analisis untuk memperbaiki kesalahan yang terjadi.

Kegiatan penelitian ini dilaksanakan di SDN 16 Simpang Haru Kota Padang sebanyak 10 guru. Teknik pengumpulan data menggunakan lembar observasi pengukuran hasil proses pembeajaran yang meliputi kemampuan perencanaan, kemampuan pelaksanaan dan kemampuan penilaian. Teknik analisis data terdiri dari data kuantitatif. Data kuantitatif untuk menganalis hasil lembar observasi:

1. Menghitung nilai rata-rata pelaksanaan pembelajaran

Adapun rumus yang digunakan yaitu

$P=\frac{\text { Skoryang didapat }}{\text { Skormaksimal }} x 100$

2. Menghitung ketuntasan klasikal

$X=\frac{\text { Jumlah guruyang mendapatkan wilai } \geq 75}{\text { Jumlah semua guru }} x 100$

Adapun indikator keberhasilan PTS ini adalah keterampilan guru dalam melasanakan proses pembelajaran mendapakan skor minimal 75 dengan ketuntasan belajar klasikal 75\%.

\section{HASIL DAN PEMBAHASAN}

Penelitian ini diawali dengan tahapan perencanaan yang bertujuan untuk merancang proses perbaikan yang dilaksanakan. Pada tahapan perencanaan terdiri dari mengatur pertemuan dengan guru, sosialisasi kegiatan, perancangan scenario kegiatan, dan menyusun instrument penelitian. Setelah semua kegiatan pada tahapan perencanaan diselesaikan maka selanjutnya masuk kepada tahap pelaksanaan.

Pada kegiatan pelaksanaan peneliti memberikan pembinaan kepada guru mengenai pengembangan pelaksanaan dan system penilaian pembelajaran kurikulum 2013 dengan menggunakan model kooperatif tipe group investigation. Kemudian guru diminta untuk mengembangkan RPP dan penilaian hasil belajar. Setelah guru mengembangkan RPP dan penilaian hasil belajar, guru diminta untuk duduk berkelompok dengan guru lainnya. Didalam kelompok masing-masing guru saling berdiskusi mengenai RPP dan penilaian hasil belajar yang dikembangkan serta saling memperbaiki kesalahan. selain itu pada kegiatan tersebut guru juga diminta untuk melaksanakan kegiatan micro teaching dan guru lain memberikan penilaian 
Jurnal PAJAR (Pendidikan dan Pengajaran)

Volume 5 Nomor 5 September 2021 | ISSN Cetak : 2580 - 8435| ISSN Online : 2614 - 1337

DOI : http://dx.doi.org/10.33578/pjr.v5i5.8525

terhadap kegiatan micro teaching yang diberikan. Hasil kegiatan guru berupa pengembangan RPP, pengembangan penilaian dan kegiatan micro teaching kemudian dinilai. Adapun hasil penilaianya dapat dilihat pada table berikut:

Tabel 1. Rekapitulasi Penilaian Siklus 1

\begin{tabular}{lr}
\hline \multicolumn{1}{c}{ Aspek } & $\begin{array}{r}\text { Skor } \\
\text { Rata-Rata }\end{array}$ \\
\hline Perancangan RPP & 67.35 \\
Perancangan penilaian & 63.17 \\
Pelaksanaan Pembalajaran & 68.45 \\
Rata-rata & 66.32 \\
\hline
\end{tabular}

Dari tabel 1 tersebut dapat dilihat bahwa guru mendapatkan skor rata-rata 66.32. Hasil pengamatan tersebut kemudian dianalisi pada tahapan refleksi. Pada tahapan refleksi dilakukan analisis terhadap temuan yang dilakukan selama proses pelaksanaan. Berdasarkan temuan didapatkan skor 66.32. Hal ini membuktikan bahwa belum tercapainya indicator keberhasilan yang ditetapkan. Selain itu pada berdasarkan lembar pengamatan juga ditemukan beberapa kegiatan yang belum maksimal yaitu guru belum mampu menyesuaiakn antara materi pelajaran dengan media pembelajaran. Selain itu terdapak bebera Langkah model kooperatif tipe group investigation yang belum dilaksanakan oleh guru pada kegiatan micro teching. Oleh sebab itu maka peneliti dan guru sepakat untuk melanjutkan perbaikan pada siklus kedua.

Kegiatan perancanaan pada siklus kedua sama dengan perencanan siklus pertama yaitu mengatur pertemuan dengan guru, sosialisasi kegiatan, perancangan scenario kegiatan, dan menyusun instrument penelitian. Setelah semua kegiatan pada tahapan perencanaan diselesaikan maka selanjutnya masuk kepada tahap pelaksanaan.

Pada kegiatan pelaksanaan peneliti memberikan pembinaan Kembali kepada guru mengenai pengembangan pelaksanaan dan system penilaian. Pada kegiatan ini peneliti meminta guru untuk mengembangkan RPP dan penilaian hasil belajar. Setelah guru mengembangkan RPP dan penilaian hasil belajar, guru diminta untuk duduk berkelompok kembali dengan guru lainnya. Didalam kelompok masing-masing guru saling berdiskusi mengenai RPP dan penilaian hasil belajar yang dikembangkan serta saling memperbaiki kesalahan yang ada. selain itu pada kegiatan tersebut guru juga diminta untuk melaksanakan kegiatan micro teaching dan guru lain memberikan penilaian terhadap kegiatan micro teaching yang diberikan.

Hasil kegiatan guru berupa pengembangan RPP, pengembangan penilaian dan kegiatan micro teaching kemudian dinilai. Adapun hasil penilaianya dapat dilihat pada table berikut:

Tabel 2. Rekapitulasi Penilaian Siklus 2

\begin{tabular}{lr}
\hline \multicolumn{1}{c}{ Aspek } & $\begin{array}{c}\text { Skor } \\
\text { Rata-Rata }\end{array}$ \\
\hline Perancangan RPP & 88.12 \\
Perancangan penilaian & 83.98 \\
Pelaksanaan Pembalajaran & 84.89 \\
Rata-rata & 85.66 \\
\hline
\end{tabular}

Dari tabel 2 tersebut dapat dilihat bahwa guru mendapatkan skor rata-rata 85.66. Hasil pengamatan tersebut kemudian dianalisi pada tahapan refleksi. Pada tahapan refleksi dilakukan 
analisis terhadap temuan yang dilakukan selama proses pelaksanaan. Berdasarkan temuan didapatkan skor 85.66. Hal ini membuktikan bahwa telah tercapainya indicator keberhasilan yang ditetapkan. Selain itu pada berdasarkan lembar pengamatan juga ditemukan bahwa guru telah melaksanakan semua kegiatan dengan benar. Maka berdasarkan kesepakatan dinyatakan bahwa penelitian dicukupkan pada siklus kedua. Adapun peningkatan kemampuan guru dapat dilihat pada gambar berikut:

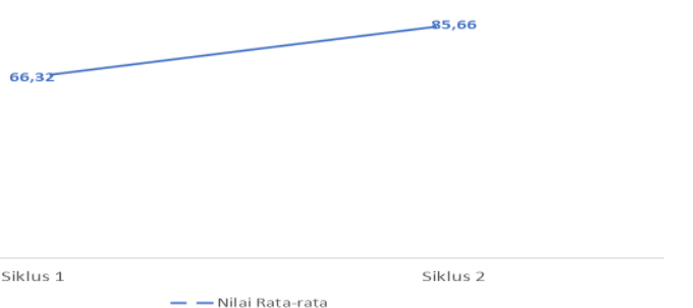

\section{Gambar 1. Peningkatan Keterampilan Guru dalam Proses Pembelajaran}

Dari gambar 1 tersebut terlihat adanya peningkatkan kemampuang proses pembelajaran guru melalui kegiatan diskusi KKG. Hasil penelitian ini didukung oleh penelitian yang dilakukan oleh Osnal et al (2016) yang menyatakan bahwa kegiatan KKG dapat meningkatkan kemampuan guru dalam mengembangkan instrument hasil belajar. Penelitian memiliki kesamaan yaitu menggunakan KKG untuk meningkatkan profesionalisme guru namun menjadi temuan yang berbeda bahwa kegiata KKG pada penilitian ini dapat meningkatkan kemampuan proses pembelajaran guru sekolah dasar yang meliputi perencanaan pembelajaran, pelaksanaan pembelajaran dan penilaian hasil belajar menggunakan model pembelajaran kooperatif tipe group investigation.

KKG merupakan sebuah wadah bagi guru untuk dapat meningkatkan kemampuan professional guru (Rezi and Asteria, 2020). KKG merupakan sebuah pendekatan yang terarah dan efektif dalam mengembangkan kinerja guru (Umah, 2016). Kinerja guru merupakan hal penting dalam tercapai nya tujuan pembelajaran. Guru menjadi kunci keberhasilan system Pendidikan. KKG menjadi salah satu bagian dari sistem pembinaan professional yang dianjurkan sekaligus dibina oleh Kementrian Pendidikan dan Kebudayaan. Kelompok kerja guru merupakan wadah pertemuan professional guru sekolah dasar yang bersifat aktif, kompak dan akrab membahas berbagai masalah professional kependidikan dengan prinsip dari guru, oleh guru dan untuk guru dalam rangka pelaksanaan tugas dan fungsinya disekolah (Al Rasyid, 2017). Pembentukan KKG berangkat dari kesadaran bahwa guru sebagai profesi dalam meningkatkan kualitas sumber daya manusia perlu terus menerus berusaha meningkatkan kemampuanya dalam melaksanakan pendidikan dan memberi layanan terhadap siswa didalam sekolah maupun diluar sekolah (Palattei and Sufemi, 2020). Hal inilah yang melatarbelakangi terjadinya peningkatkan keterampilan guru dalam proses pembelajaran.

\section{SIMPULAN DAN REKOMENDASI}

Berdasarkan penelitian yang dilakukan ditemukan guru mendapatkan skor rata-rata keterampilan pada siklus 1 sebesar 66,32 dan mendapatkan skor rata-rata pada siklus 2 sebesar 85,66 . Hal ini menyimpulkan bahwa terjadinya peningkatan keterampilan proses pembelajaran guru melalui kegiatan KKG. Penelitian ini menyarankan agar perlu kesepakatan jadwal dengan guru agar pelaksanaan supervisi dapat terlaksana dengan optimal. 
Jurnal PAJAR (Pendidikan dan Pengajaran)

Volume 5 Nomor 5 September 2021 | ISSN Cetak : 2580 - 8435| ISSN Online : 2614 - 1337

DOI : http://dx.doi.org/10.33578/pjr.v5i5.8525

\section{DAFTAR PUSTAKA}

Al Rasyid, H. (2017). Fungsi Kelompok Kerja Guru (KKG) Bagi Pengembangan Keprofesionalan Guru Sekolah Dasar. Sekolah Dasar: Kajian Teori dan Praktik Pendidikan, 24(2), 143-150.

Alwi, M. (2009). Peran kelompok kerja guru (KKG) dalam meningkatkan profesional guru sains sekolah dasar Kecamatan Suralaga. Educatio, 4(2), 101-117.

Dzemidzic Kristiansen, S., Burner, T., \& Johnsen, B. H. (2019). Face-to-face promotive interaction leading to successful cooperative learning: A review study. Cogent Education, 6(1), 1674067.

Eliyasni, R., Kenedi, A. K., \& Sayer, I. M. (2019). Blended Learning and Project Based Learning: The Method to Improve Students' Higher Order Thinking Skill (HOTS). Jurnal Iqra': Kajian Ilmu Pendidikan, 4(2), 231-248.

Gading, I. K., Ajerah, K. S., \& Japa, I. G. N. (2017, August). Cooperative Learning Model Group investigation Type and Mathematic Achievement of Elementary School Students. In 2nd International Conference on Innovative Research Across Disciplines (ICIRAD 2017) (pp. 229-232). Atlantis Press.

Genç, M. (2016). An evaluation of the cooperative learning process by sixthgrade students. Research in Education, 95(1), 19-32.

Gillies, R. M. (2016). Cooperative learning: Review of research and practice. Australian Journal of Teacher Education (Online), 41(3), 39-54.

Hakkarainen, K., Lipponen, L., \& Järvelä, S. (2013). Epistemology of inquiry and computer-supported collaborative learning. In Cscl 2 (pp. 151-204). Routledge.

Hamimah, H., Kenedi, A. K., Zuryanty, Z., \& Nelliarti, N. (2019). IMPROVING CRITICAL THINKING ABILITY BY USING THE PROBLEM-BASED LEARNING MODEL. Primary: Jurnal
Pendidikan Guru Sekolah Dasar,9(2), 173-184.

Hamimah, H., Zuryanty, Z., Kenedi, A. K., \& Nelliarti, N. (2019). The Development of the 2013 Student Curriculum Book Based on Thinking Actively in Social Context for Elementary School Students. Al Ibtida: Jurnal Pendidikan Guru MI, 6(2), 159-176.

Hastuti, R. I. (2020, October). Flipped classroom learning model with group investigation strategy to increase the enjoyment of mathematics in elementary school students. In Journal of Physics: Conference Series (Vol. 1663, No. 1, p. 012054). IOP Publishing.

Hendri, S., \& Kenedi, A. K. (2018) Pengembangan perangkat pembelajaran matematika berbasis discovery learning untuk meningkatkan kemampuan pemecahan masalah siswa kelas VIII SMP. Jurnal Inspirasi Pendidikan, 8(2), 10-24.

Hendri, S., Helsa, Y., Kenedi, A. K., \& Anita, Y. (2019, December). Elementary School Teacher Ability in Using Application Technology for Mathematics Learning Assessment in the 2013 Curriculum. In 5th International Conference on Education and Technology (ICET 2019) (pp. 446-449). Atlantis Press.

Hendri, S., Kenedi, A. K., Anita, Y., Habibi, M., \& Akmal, A. U. (2019, October). Validation of discovery learning-based to increase the ability of elementary students problem solving skills. In Journal of Physics: Conference Series (Vol. 1318, No. 1, p. 012109). IOP Publishing.

Hidayat, T. M., \& Muhson, A. (2018). The impact of think pair share and two stay two stray learning model towards learning outcomes and cooperation ability. Dinamika Pendidikan, 13(1), 119129.

Kenedi, A. K., Eliyasni, R., \& Fransyaigu, R. (2019, December). Jigsaw using animation media for elementary school. 
Jurnal PAJAR (Pendidikan dan Pengajaran)

Volume 5 Nomor 5 September 2021 | ISSN Cetak : 2580 - 8435| ISSN Online : 2614 - 1337

DOI : http://dx.doi.org/10.33578/pjr.v5i5.8525

In Journal of Physics: Conference Series (Vol. 1424, No. 1, p. 012027). IOP Publishing.

Kiswanto, A. (2017, September). The effect of learning methods and the ability of students think logically to the learning outcomes on natural sciences of grade ivs student. In 9th International Conference for Science Educators and Teachers (ICSET 2017) (pp. 1040-1046). Atlantis Press.

Kristiawan, M. (2013). The Implementation of cooperative learning in English class of favorite School of secondary high school 5 Batusangkar, West Sumatera. International Journal of Educational Administration and Policy Studies, 5(6), 85-90.

Lubis, S. (2017). Peningkatan Profesionalisme Guru PAI Melalui Kelompok Kerja Guru (KKG). Jurnal Pendidikan Agama Islam Al-Thariqah, 2(2), 189-205.

Maman, M., \& Rajab, A. A. (2016). The Implementation of Cooperative Learning Model" Number Heads Together"(" NHT") in Improving the Students' Ability in Reading Comprehension. International Journal of Evaluation and Research in Education, 5(2), 174-180.

Novita, L. D., Sarkadi, S., \& Maksum, A. (2021). Group investigation Learning in Developing 21st Century Skills of Elementary School Students. International Journal of Multicultural and Multireligious Understanding, 8(6), 268-278.

Osnal, O., Suhartoni, S., \& Wahyudi, I. (2016). Meningkatkan kemampuan guru dalam menyusun tes hasil belajar akhir semester melalui workshop di $\mathrm{kkg}$ gugus 02 kecamatan sumbermalang tahun 2014/2015. Pancaran Pendidikan, 5(1), 67-82.

Palettei, A. D., \& Sulfemi, W. B. (2019). Pengaruh kelompok kerja guru (KKG) terhadap peningkatan kompetensi pedagogik dan kemampuan menulis karya ilmiah. JPDI (Jurnal Pendidikan Dasar Indonesia), 4(2), 53-58.

Rozi, F., \& Asteria, P. V. (2020). Peningkatan kemampuan guru dalam pengembangan media pembelajaran berbasis literasi melalui KKG mini. Jurnal Minda, 1(2), 49-60.

Slavin, R. E. (2015). Cooperative learning in elementary schools. Education 3$13,43(1), 5-14$.

Sukirman, S. (2020). Efektivitas Kelompok Kerja Guru (KKG) dalam Peningkatan Kompetensi Guru. Indonesian Journal of Education Management \& Administration Review, 4(1), 201-208.

Sukirno, S., Kenedi, A. K., \& Nelliarti, N. (2020). Peningkatan Kemampuan Literasi Informasi Siswa Sekolah Dasar Melalui Model Project Based Learning. In SEMINAR NASIONAL PENINGKATAN MUTU PENDIDIKAN (Vol. 1, No. 1, pp. 435439).

Umah, A. N. (2016). Upaya Peningkatan Profesionalisme Guru Melalui Kegiatan Kelompok Kerja Guru Pendidikan Agama Islam Di Kecamatan Samigaluh, Kabupaten Kulonprogo. Millah: Jurnal Studi Agama, 14(1), 201-220.

Yeh, Y. L., Lan, Y. J., \& Lin, Y. T. R. (2018). Gender-related differences in collaborative learning in a 3D virtual reality environment by elementary school students. Journal of Educational Technology \& Society, 21(4), 204-216.

Yus, H. (2020). Improving Teachers'skills In Designing Hots (Higher Order Thinking Skills) Questions Through Teacher Work Group (KKG). JURNAL PAJAR (Pendidikan dan Pengajaran), 4(6), 11981205.

Zaman, B. (2020). Implementation of Cooperative Learning Strategies in Islamic Religious Education. IJECA (International Journal of Education and Curriculum Application), 3(2), 91-97. 